\title{
Characterization and Genetic Control of Alkaline Phosphatase Isozymes in Chicken Liver
}

\author{
Yoshinori Tamaki and Shozo Watanabe \\ National Institute of Animal Industry, Chiba-shi 280
}

(Received November 28, 1978)

\begin{abstract}
The existence and characterization of chicken liver alkaline phosphatase isozymes by neuraminidase, urea and heat treatments using horizontal polyacrylamide gel electrophoresis were investigated to clarify the relationship between plasma and liver alkaline phosphatase isozymes in 5-week-old Single Comb White Leghorn male chicks. Liver alkaline phosphatase comprised three isozymes. The zymogram of an individual chicken liver had two bands, either the faster $(\mathrm{F})$ or the slower $(\mathrm{S})$ moving band by isozyme types and the $\mathrm{B}$ band irrespective of isozyme types. The $\mathrm{B}$ band was labile to urea $(4 \mathrm{M})$ and heat $\left(60^{\circ} \mathrm{C}\right)$ treatments. Mobility of the $\mathrm{S}$ band in liver was not affected by neuraminidase. The treatment had a reduced migration rate of the $F$ band equal to that of the $\mathrm{S}$ band and the $\mathrm{B}$ band of both types closer to the origin. These results agreed with those in plasma and thus the genetic control of plasma alkaline phosphatase isozymes was suggested to be applicable to the liver alkaline phosphatase isozymes.
\end{abstract}

Jap. J. Zootech. Sci., 50 (7): 488-492, 1979

Very recently TAMAKI et al. ${ }^{\prime \prime}$ reported duodenum alkaline phosphatase isozymes in chicken, in relation to plasma alkaline phosphatase isozymes. The duodenum alkaline phosphatase were composed of three isozymes, F, S and B bands. They had the essentially identical characteristics to plasma alkaline phosphatase isozymes and thus the genetic control of plasma alkaline phosphatase isozymes was suggested to be applicable to the duodenum alkaline phosphatase isozymes. However, no studies have been reported as to the existence and characterization of alkaline phosphatase isozymes in other tissues of chicken.

The present study was conducted to clarify the relationship between chicken plasma and liver alkaline phosphatase isozymes and to discuss the genetic control of liver alkaline phosphatase isozymes.

\section{Materials and Methods}

Plasma and liver samples were taken in 5-week-old Single Comb White Leghorn males (Goto Hatchery Co., Ltd., Japan) kept in National Institute of Animal Industry. They were stored at. $-20^{\circ} \mathrm{C}$ immediately after collecting until homogenizing. Within one week after freezing, the liver sample was thawed and cut into very small pieces with a stainless steel scissors, then homogenized with equal volume of $0.1 \mathrm{M}$ Tris- $\mathrm{HCl}$ buffer ( $\mathrm{pH} 8.0$ ) containing $0.05 \mathrm{M} \mathrm{MgCl}$ for 2 minutes at $2^{\circ} \mathrm{C}$ by IKA-Ultra Turrax Laboratory Equipment (Janke \& Kunkel Co., Ltd., West Germany) and supernatant 
was obtained by centrifuging at $6,000 \mathrm{rpm}$ for $30 \mathrm{~min}$ at $4^{\circ} \mathrm{C}$ and ultracentrifuging at $38,000 \mathrm{rpm}$ for one hour at the same temperature. The solution obtained was removed any containing tissue particles. The supernatant was stored at $-20^{\circ} \mathrm{C}$.

The samples obtained above were subjected to horizontal polyacrylamide gel (5\%) electrophoresis previously described by TAMAKI and TANABE ${ }^{2}$. Alkaline phosphatase isozyme was detected by using $\beta$-naphthyl acid phosphate sodium salt (Sigma Chemical Co., U.S.A.) as a substrate, and Fast blue B salt (Sigma Chemical Co., U.S. A.) as a dye-coupler.

To examine the effect of neuraminidase treatment, samples were incubated with $0.5 \mathrm{mg}$ of neuraminidase (Sigma Chemical Co., U.S. A.) per $\mathrm{ml}$ for 1 hour at $37^{\circ} \mathrm{C}$ as described by $\mathrm{LAW}^{3}$. To examine the effect of urea treatment, liver samples were preincubated for $15 \mathrm{~min}$ at $37^{\circ} \mathrm{C}$ with $4 \mathrm{M}$ urea as reported by TAMAKI and MORICHI ${ }^{4}$. The samples were diluted 1:1 with physiological saline containing $8 \mathrm{M}$ urea to make the samples change $4 \mathrm{M}$ urea concentration. To examine the effect of heat treatment, liver samples were heated at $60^{\circ} \mathrm{C}$ for $10 \mathrm{~min}$ as reported by TAMAKI and MoRICHI ${ }^{4}$. After heating, supernatants were obtained by centrifuging at $3,000 \mathrm{rpm}$ for $10 \mathrm{~min}$ at room temperature. After preincubation, the samples were subjected to electrophoresis.

\section{Results}

Fig. 1 shows a comparison of isozyme pattern in plasma and liver alkaline phosphatase in chicken at 5 weeks of age. Plasma and liver alkaline phosphatase in the same individuals had the same isozyme type. Thus, the individuals with the $\mathrm{F}$ or $\mathrm{S}$ type in plasma alkaline phosphatase showed the $\mathrm{F}$ or $\mathrm{S}$ type in liver alkaline phosphatase, respectively. The zymogram of an individual chicken liver had two bands, either the faster moving band designated as $\mathrm{F}$ band or the slower designated as $\mathrm{S}$ band by isozyme types and the band which had a slower migrating rate to the $\mathrm{F}$ or $\mathrm{S}$ band irrespective of isozyme types designated as B band. In plasma alkaline phosphatase, the apparent relative activity of the $\mathrm{F}$ or $\mathrm{S}$ band detected by electrophoresis was higher than that of the B band, while, in liver, the B band had higher relative activity than the $\mathrm{F}$ or $\mathrm{S}$ band.

Fig. 2 shows the effect of neuraminidase treatment on chicken liver alkaline phosphatase isozymes. When the liver samples were treated with neuraminidase, the mobility of the $\mathrm{F}$ band was equal to the $\mathrm{S}$ band, while the $\mathrm{S}$ band was not affected at all by the treatment. The $\mathrm{B}$ band of both types was retarded up to the position closer to the origin.

Fig. 3 shows the effects of urea $(4 \mathrm{M})$ and heat $\left(60^{\circ} \mathrm{C}, 10 \mathrm{~min}\right)$ treatments on the isozyme pattern on chicken liver alkaline phosphatase. The $\mathrm{B}$ band was labile to urea and heat treatments irrespective of isozyme types, while both $\mathrm{F}$ and $\mathrm{S}$ bands were stable by either treatment.

These results by urea, heat and neuraminidase treatments agreed essentially with those in chicken plasma and duodenum alkaline phosphatase isozymes ${ }^{1,4,5}$. 
When the samples were centrifuged at $6,000 \mathrm{rpm}$, irrelative band to $\mathrm{F}, \mathrm{S}$ or $\mathrm{B}$ band, designated as the third band, was detected as shown in Fig 4. The third band migrated close to the origin irrespective of isozyme types. It was not observed electrophoretically, when the samples were centrifuged at $38,000 \mathrm{rpm}$ and/or concentrated by Diaflo membrane XM 100A (Amicon Co., Ltd., U.S. A.). And it was not affected by neuraminidase (Fig. 4). Therefore, the third band is not identical to "the B band" retarded by neuraminidase.
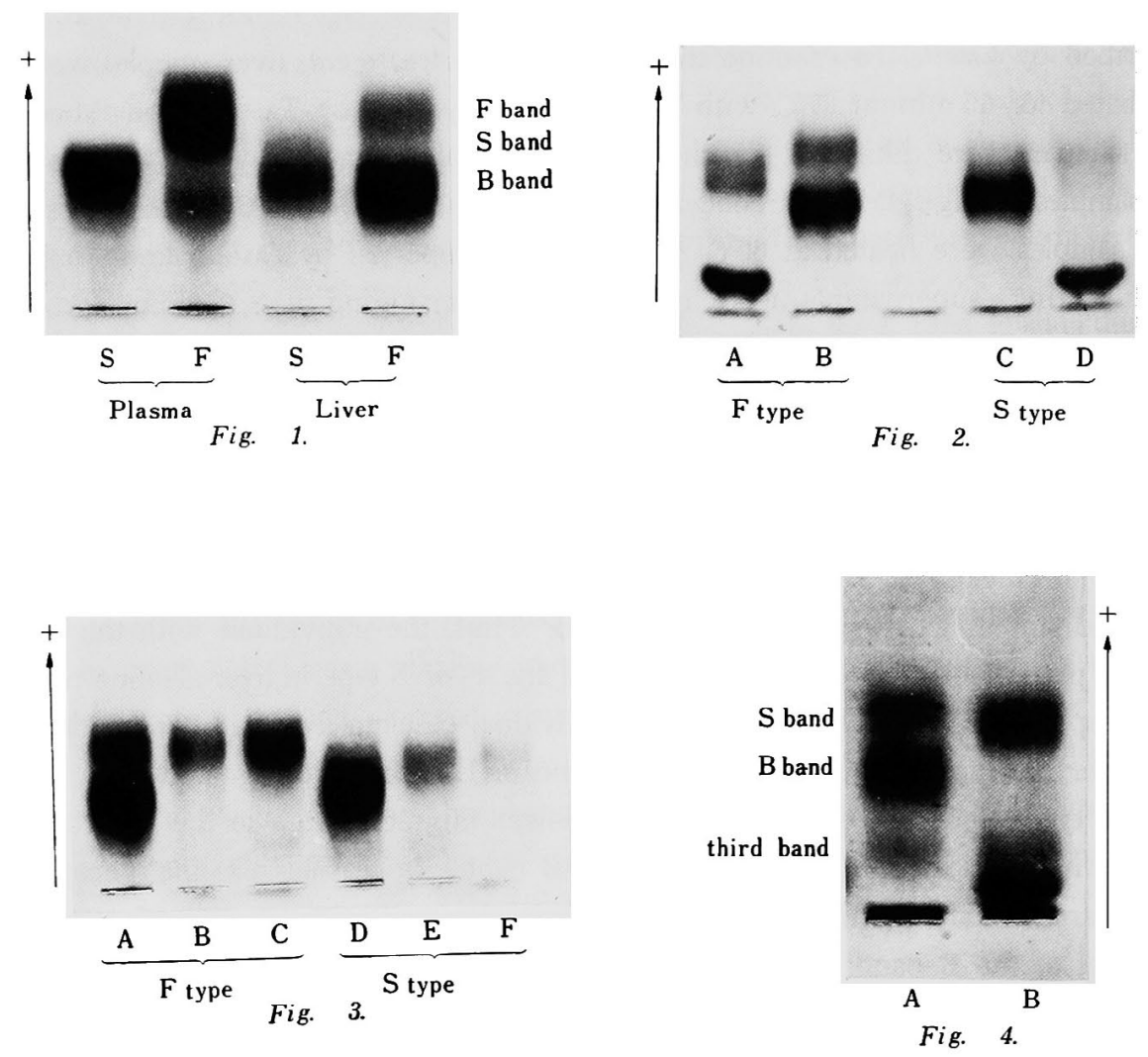

\section{Legends for Figures}

Fig. 1. A comparison of zymograms of alkaline phosphatase isozymes in plasma and liver samples in 5-week-old Single Comb White Leghorn chicks.

Fig. 2. Alteration of the mobility of alkaline phosphatase isozymes in chicken liver samples treated with neuraminidase. Samples $B$ and $C$ were untreated, samples $A$ and $D$ were treated with neuraminidase.

Fig. 3. Effects of $4 \mathrm{M}$ urea and heat $\left(60^{\circ} \mathrm{C}, 10 \mathrm{~min}\right)$ treatments on the isozyme pattern of alkaline phosphatase in chicken liver samples. Samples A and D: untreated; B and E; urea treatment; $\mathrm{C}$ and $\mathrm{F}$; heat treatment.

Fig. 4. The zymogram in which the irrelative band to the $\mathrm{F}, \mathrm{S}$ or $\mathrm{B}$ band, designated as third band, was detected. Sample A was untreated; sample B was treated with neuraminidase. 


\section{Discussion}

The $\mathrm{F}, \mathrm{S}$ or $\mathrm{B}$ band in the chicken liver alkaline phosphatase can be considered to be identical to the $\mathrm{F}, \mathrm{S}$ or $\mathrm{B}$ band in plasma, respectively, based on the characteristics in migration rate and effects of neuraminidase, urea and heat treatments on the different three isozymes; that is, the genetic control of plasma alkaline phosphatase isozymes in chicken may be applicable to the liver alkaline phosphatase isozymes. In this connection, TAMAKI $e t$ al. ${ }^{1}$ recently elucidated that the duodenum alkaline phosphatase isozymes had the essentially identical characteristics to plasma alkaline phosphatase isozymes by the above treatment. Therefore, the chicken liver and duodenum alkaline phosphatase isozymes can be considered to be under the same genetic control.

In $1969, \mathrm{BIDE}^{(6)}$ intended to differentiate tissue alkaline phosphatase quantitatively by urea inhibition test. Through the results of our previous and present studies ${ }^{1,4}$, the differences in the response to urea between liver and duodenum in his experiment can be explained by the differences in relative contributions of the $F$ (or $S$ ) and the $\mathrm{B}$ bands between both tissues, because the $\mathrm{F}$ (or $\mathrm{S}$ ) band is stable to urea inhibition.

Before full understanding physiological meanings of plasma alkaline phosphatase, the genetic relationship between plasma and tissue alkaline phosphatase isozymes and the relative contribution of the tissue alkaline phosphatase isozymes to plasma alkaline phosphatase activity should be elucidated. As for the former, in the case of human alkaline phosphatase, the tissue specific isozymes for bone, liver, placentae and small intestine have been demonstrated with the differences in migration rate and characterization by urea, heat and neuraminidase so on ${ }^{7}$. On the other hand, in the case of chicken alkaline phosphatase, the results in the present study seem to suggest that all of tissue alkaline phosphatase isozymes are essentially under the same genetic control.

The third band as shown in Fig 4 appears to be higher molecular weight complex of alkaline phosphatase isozymes containing tissue particles than $\mathrm{F}, \mathrm{S}$ and $\mathrm{B}$ bands, as alkaline phosphatase from high molecular weight complex of lipoprotein in tissues $^{8}$. This view may be substantiated by its disappearance after removing any tissue particles by ultracentrifugation.

\section{References}

1) Tamaki, Y., S. Watanabe and S. Moriuchi, Anim. Blood Grps Biochem. Genet., 8: 33-38. 1977.

2) TAMakI, Y., and Y. Tanabe, Poultry Sci., 49: 798-804. 1970.

3) LAw, G. R. J., Science, 156: 1106-1107. 1967.

4) TAMAKI, Y., and T. MorichI, Anim. Blood Grps Biochem Genet., 7: 179-184. 1976.

5) TaMakı, Y., Anim. Blood Grps Biochem. Genet., 6: 195-200. 1975.

6) Bide, R.W., Technicon Symposia, 169-173. 1969.

7) Moss, D. W., Enzyme, 20: 20-34. 1975.

8) Chang, C-H., and F. Moog, BBA, 258: 154-165. 1972. 


\section{鶏肝アルカリ性ホスファターゼアイソザイムの遺伝支配}

玉置祯紀・渡辺昭三

農林水産省畜沙試験場，千葉市 280

5 週歯会の白色レグホーン種を供試鵎として，水平ポリ クリルアミドゲル電気泳動を行ない, 鵎肝アルカリ性 スファターゼフインザイムの遗伝支配について研究し 、肝フルカリ性ホスファターゼは, 鶏血獎および十二 腸フルカリ性ホスファターゼの場合と同様に，Fと S イプとからなり，それぞれのタイプは 2 本のバンドか 成っていた。一方，尿素，熱およびノイラミニダーゼ
処理の肝アルカリ性ホスファターゼフイソザイムにおよ

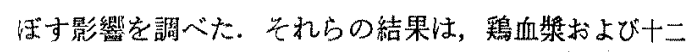
指腸フルカリ性ホスファターゼの婸合と基本的に一致し ていた。これらの事実から，肝アルカリ性ホスブァター ゼは，血䊢および十二指腸アルカリ性ホスファターゼと 基本的に同一の遺伝支配の下にあることが推察された.

日畜会報，50(7)：488-492，1979 